\title{
EFFECTS OF STORAGE CONDITIONS AND STORAGE PERIOD ON NUTRITIONAL AND OTHER QUALITIES \\ OF STORED YAM (Dioscorea spp) TUBERS
}

Osunde $\mathrm{ZD}^{1 *}$ and $\mathrm{BA}$ Orhevba ${ }^{1}$

*Corresponding author Email: zinashdo@yahoo.com

${ }^{1}$ Federal University of Technology, Minna, Nigeria 


\section{ABSTRACT}

Yam is one of the preferred staple foods in West Africa. The annual vegetative cycle of yam necessitates a long period of storage to make it available all year round. The major problems in yam tuber storage are sprouting, respiration and transpiration, which cause weight and quality losses. In this work, the effects of storage conditions and storage period on the nutritional and other qualities of stored yam tubers were investigated. Storage conditions used were two traditional yam barns, one with fan to aid air circulation and the other without. A total of 216 tubers of yam (Dioscorea roundata) "Giwa" variety with 108 tubers in each barn, were stored in the barns. Parameters evaluated were temperature and relative humidity of the storage environment, signs of deterioration of the tuber such as sprouting, weight loss and rotting and some nutritional parameters (carbohydrate, calcium, phosphorus, crude fibre, crude fat, crude protein, ash and moisture contents). Temperature and relative humidity were measured three times a week and four times a day at $0800 \mathrm{~h}, 1200 \mathrm{~h}$, $1600 \mathrm{~h}$ and $2000 \mathrm{~h}$. The results showed that average temperature and relative humidity in the barn with fan were slightly lower than that of the barn without fan. These differences were statistically significant for April, May and June at $\mathrm{P} \leq 0.1$. Tubers stored in the barn with fan had the least sprout weight and least weight loss. At the end of a 3-month period, the tubers in the ventilated barn showed $4.7 \%$ less weight loss compared to the barn without fan. The difference in sprout weights and weight loss between the structures was statistically significant at $\mathrm{P} \leq 0.05$. Also, tubers stored in the barn with fan had the least percentage of rotten tubers (1.85\% of stored tubers) compared to the tubers stored in the barn without fan (12.03\%). A reduction of some of the nutritional content was also observed during the six months of storage period. From these results it can be concluded that intermittent air flow on stored yam tubers reduces sprouting, weight loss and rot development, thus reducing the overall loss in stored yam tuber. However, moisture, crude protein, carbohydrates, phosphorus and calcium contents of the tuber reduced significantly in the two barns studied.

Key words: Yam, storage conditions, nutritional, content 


\section{INTRODUCTION}

Yam belongs to the genus Dioscorea (Family Dioscoreaceae) and is the second most important tropical root crop in West Africa, next to cassava, [1]. Yams originated in the Far East and spread westwards. Today, yams are grown widely throughout the tropics. In 2005, 48.7 million tones of yam were produced world wide. West and Central Africa account for about $94 \%$ of world production, Nigeria being the major producer [2]. In the South Pacific, yam is a significant food crop, accounting for over $20 \%$ of the total dietary calorie intake [1]. Besides their importance as food source, yams also play a significant role in the socio-cultural lives of some producing regions like the celebrated New Yam Festival in West Africa.

Yams store relatively longer in comparison with other tropical fresh produce and therefore, well stored yam represents stored wealth which can be sold all year round by the farmer [1]. Good storage should therefore maintain tubers in their most edible and marketable condition by preventing large moisture losses, spoilage by pathogens, attack by insects and animals, and sprout growth. Methods of storage vary from delayed harvesting, storage in simple piles or clamps to storage in buildings specially designed for that purpose, and application of sophisticated modern techniques [3]. Yam storage technique has been adequately described by researchers [4, 5].

Causes of storage losses of yam tubers include: sprouting, transpiration, respiration, rot due to mould and bacteriosis, insects, nematodes and mammals [6]. Harvested tubers are frequently attacked by several viruses, bacteria, fungi and insects. Also rodents feed on some of the harvested tubers stored in the barns [3]. Sprouting, transpiration and respiration are physiological activities which depend on the storage environment mainly temperature and relative humidity [6]. These physiological changes affect the internal composition of the tuber and result in destruction of edible material, which under normal storage conditions can often reach $10 \%$ after 3 months, and up to $25 \%$ after 5 months of storage [6].

The dry matter portion of yam tubers is mostly composed of carbohydrates, which exist primarily in the form of starch and sugars [7]. A study conducted on the chemical composition of yam tuber stored under ambient and cold room condition showed no significant differences between the means obtained for carbohydrate, fat and fiber after 72 hours of storage [8]. Onyeme and Idowu [9] studied physical and chemical changes that occur on yams stored in traditional barns. Their result shows losses in moisture, dry matter, crud protein and ascorbic acid after 120 days of storage. Consequently they recommend that farmers should not store yam tubers for a period longer than 120 days. Sahore et al. [10] studied changes in nutritional properties of yam (Dioscorea spp), green plantain (Musa spp) and cassava (Manihot esculenta) during storage. Their work shows that yam tubers under went only slight changes over a four week period of storage while cassava and green plantain could be kept only for a week without significant deterioration. Comparative analysis of yam tubers stored for 1, 5 and 8 months after harvest showed that the total amino acid content decreased slightly during the storage period [7].

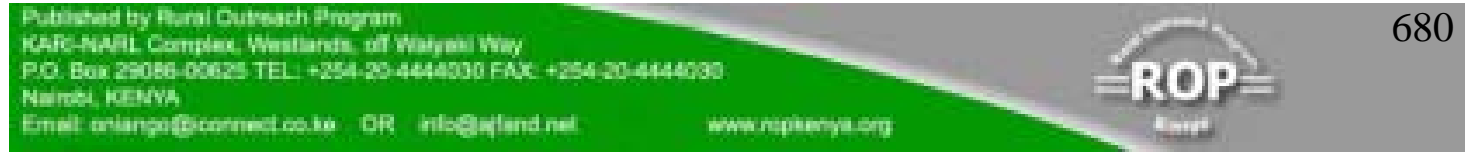


Although there is some information on the chemical composition of yam tuber, few studies have been carried out on the mineral and vitamin content. The minerals frequently measured in yam tubers are calcium, phosphorous, iron, potassium and sodium [3]. The little information available indicates that changes in mineral constituents during storage are insignificant [11].

Generally this study is aimed at improving the quality of stored yam. Specifically the work investigates and evaluates the effect of intermittent forced airflow and storage period on nutritional and other quality parameters of stored yam tubers.

\section{METHODOLOGY}

The experiment was carried out at Minna, Niger State of Nigeria, which is located at the Guinea Savannah Ecological zone. Two traditional yam barns were used for this experiment. The barns were erected in the open air, where sufficient shade and ventilation was available. The frame of the yam barn consisted of vertically erected wooden poles of $2 \mathrm{~m}$ in height and set at a distance of $1 \mathrm{~m}$ to each other, these wooden poles were stabilized by attaching horizontal poles to them. The dimensions for each barn was $2.5 \mathrm{~m}, 3.5 \mathrm{~m}$ and $2 \mathrm{~m}$, width, length and height respectively, locally knitted thatch made of dried plant stalks were wound round the frame and the top, this served as the roof and the wall. There was a slight opening between the roof and wall to allow for optimum ventilation and reduction in ambient temperature inside the barn. Two of such structures were constructed and used for the storage of yam tubers $c v$. Giwa at the Department of Agricultural Engineering Federal University of Technology, Minna, Nigeria. One of the barns had a fan that operated at $27.24 \mathrm{~m} / \mathrm{s}$ speed and rotated at $180^{\circ}$, this is to enable all the tubers to be evenly ventilated. A total off 108 freshly harvested tubers obtained from a farm in Garatu, Niger State, Nigeria were stored in each barn and used for the study.

The tubers were grouped into six groups of 18 tubers each and numbered. In order to reduce bruising, facilitate ventilation, weighing and observation, the tubers were arranged on a wooden platform that was placed on the floor of the barn. Parameters monitored during storage were temperature and relative humidity of the storage environment and some quality parameters of stored yam. The quality parameters determined were weight loss, rate of sprouting, rot development and some nutritional parameters such as carbohydrates, calcium, phosphorus, crude protein, crude fat, crude fiber, and ash and moisture contents. The tubers were stored for 6 months between January and June.

\section{Measurements}

Environmental parameters: Temperature and Relative humidity were measured three times a week and four times a day (0800h, 1200h, 1600h and 2000h). These times were chosen for even distribution of measurements. Temperature and humidity readings were taken using a Mebus 4.0 Digital thermo-hygrometer. Readings were taken at

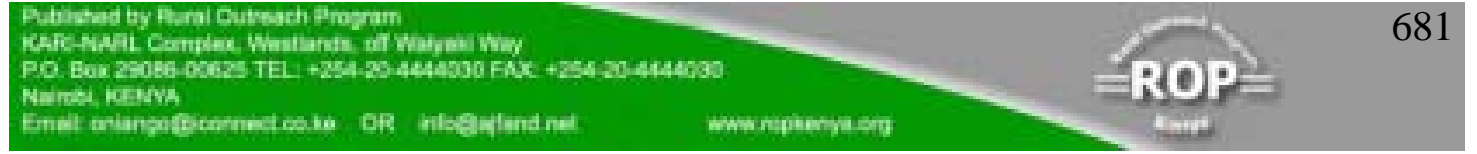


three different locations in the barn. Two measurements were taken beside the yam tuber at $10 \mathrm{~cm}$ above the wooden platform and at $10 \mathrm{~cm}$ above the tubers.

Physiological Parameters: Weight loss, sprouting and rotting were evaluated during the storage period. To evaluate the weight loss the tubers were weighed monthly starting from the first day of storage. The percentage weight loss for each month was computed based on the initial tuber weight. To assess sprouting rate, de-sprouting was carried out manually, this was done bi monthly and the sprouts weighed and average monthly sprouting was computed. During weighing the tubers were visually examined for rot development and the numbers of rotten tubers were recorded.

Nutritional Parameters: Nutritional analysis of the stored yam tubers was carried out during the course of the storage period. This was done at the beginning, after three months of storage and at the end of the storage period of six months. The nutritional parameters evaluated were moisture, ash, crude protein, crude fat, crude fibre, and phosphorus, calcium and carbohydrate contents. Three tubers from each barn were randomly selected and used for the nutritional analysis and the average for each was calculated. The oven method was used to determine the moisture content [12], the protein content was determined using the Kjedahl method while the ash content, crude fat, crude fibre, phosphorus, calcium and carbohydrate were evaluated based on the A.O.A.C methods of analysis [13]. 


\section{RESULTS}

\section{Environmental Parameters}

\section{Temperature in the Barns}

Figure 1 shows the monthly average maximum and minimum temperature in the two barns.

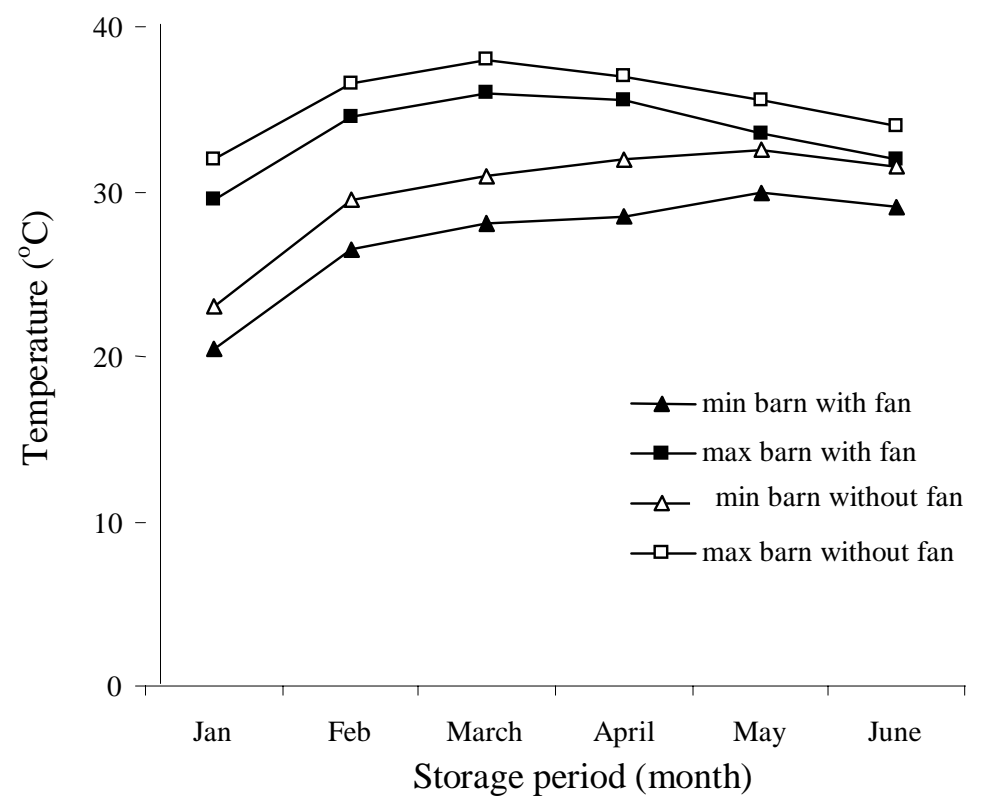

Figure 1: Monthly average maximum and minimum temperature in the two bans.

The temperature fluctuated between 20.5 and $35{ }^{\circ} \mathrm{C}$ in the barn with fan while in the barn without fan it fluctuated between 23 and $39.7^{\circ} \mathrm{C}$. The average daily temperature in the barn with fan was between $2-6{ }^{\circ} \mathrm{C}$ less than that of the barn without fan. Highest daily temperature in the two barns was recorded at 4 pm while the lowest was recorded at $8 \mathrm{am}$. The minimum and maximum temperature variation was higher between the months of January to April, which was between 9 and $12{ }^{\circ} \mathrm{C}$ while in May and June it was between 5 and $6.5^{\circ} \mathrm{C}$. The temperature differences between the two structures were statistically significant for April, May and June at $\mathrm{P} \leq 0.1$.

Relative Humidity in the Barns relative humidity in the barn with fan ranged between 28 and $61 \%$ while in the barn without fan it ranged between 24 and 55\%. The highest relative humidity in both barns was recorded at 8 am while the lowest was at $4 \mathrm{pm}$ (Fig. 2). The daily humidity variation ranges from $2 \%$ in January to about $20 \%$ in March and April. In January and February the relative humidity was at its lowest, however it increased rapidly between March and June. The difference in relative humidity between the two barns was statistically significant for April and June at $\mathrm{P} \leq 0.05$ 


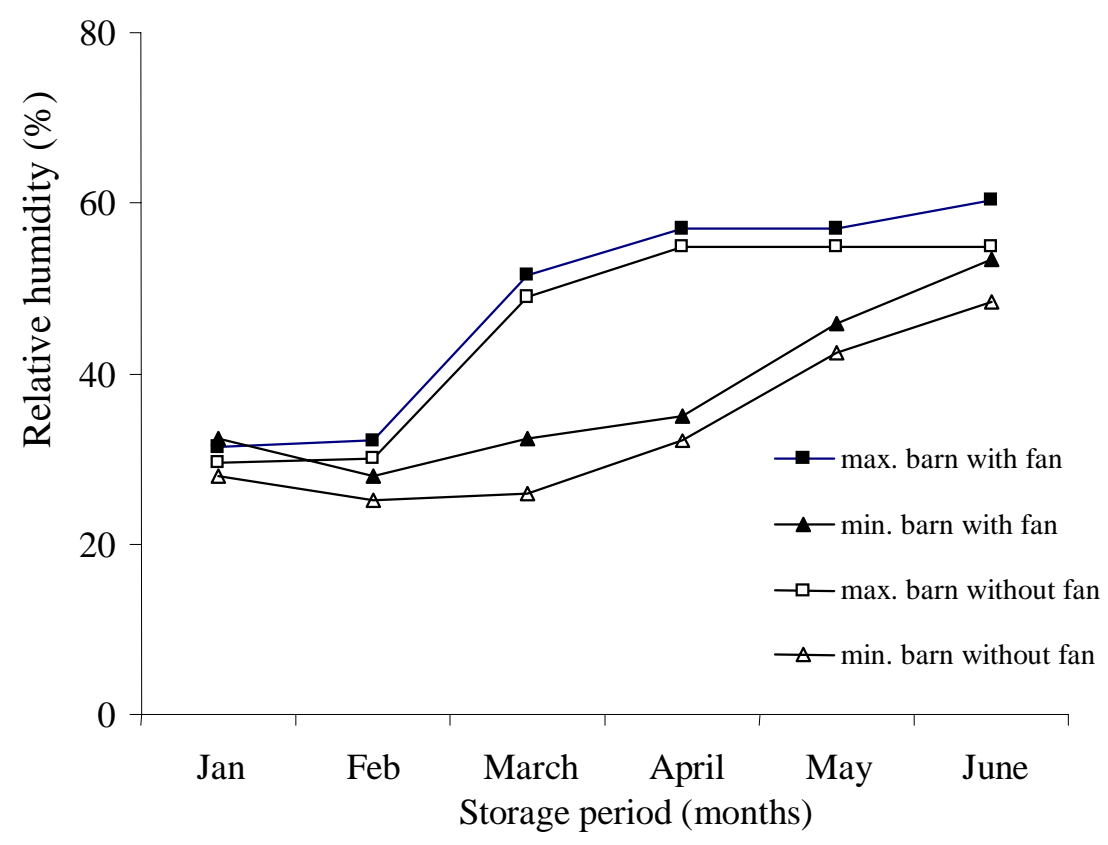

Figure 2: Average monthly maximum and minimum relative humidity in the two barns.

\section{Physiological Parameters \\ Sprouting}

Figure 3 shows the sprouting rate in the two structures and for the storage period. From the figure tubers stored in the barn with fan showed less sprout weights than those stored in the barns without fan. The difference in sprout weights between the structures was statistically significant $(\mathrm{p}<0.05)$.

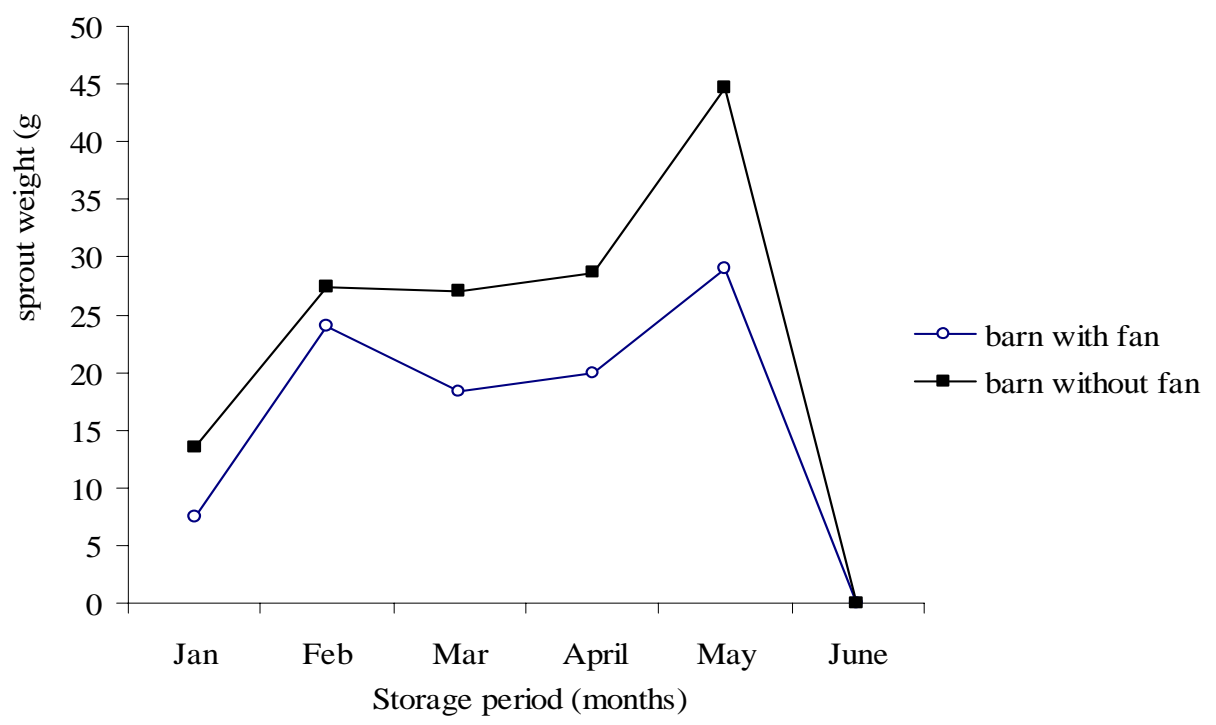

Figure 3: $\quad$ Monthly average sprout weight 


\section{Weight Loss}

Figure 4 shows the percentage weight loss of tubers stored in the two barns for six month of storage period. It shows that the barn with fan had the least weight loss throughout the period of storage. The difference in weight loss between the tubers stored in the two barns was statistically significant $(\mathrm{p}<0.05)$.

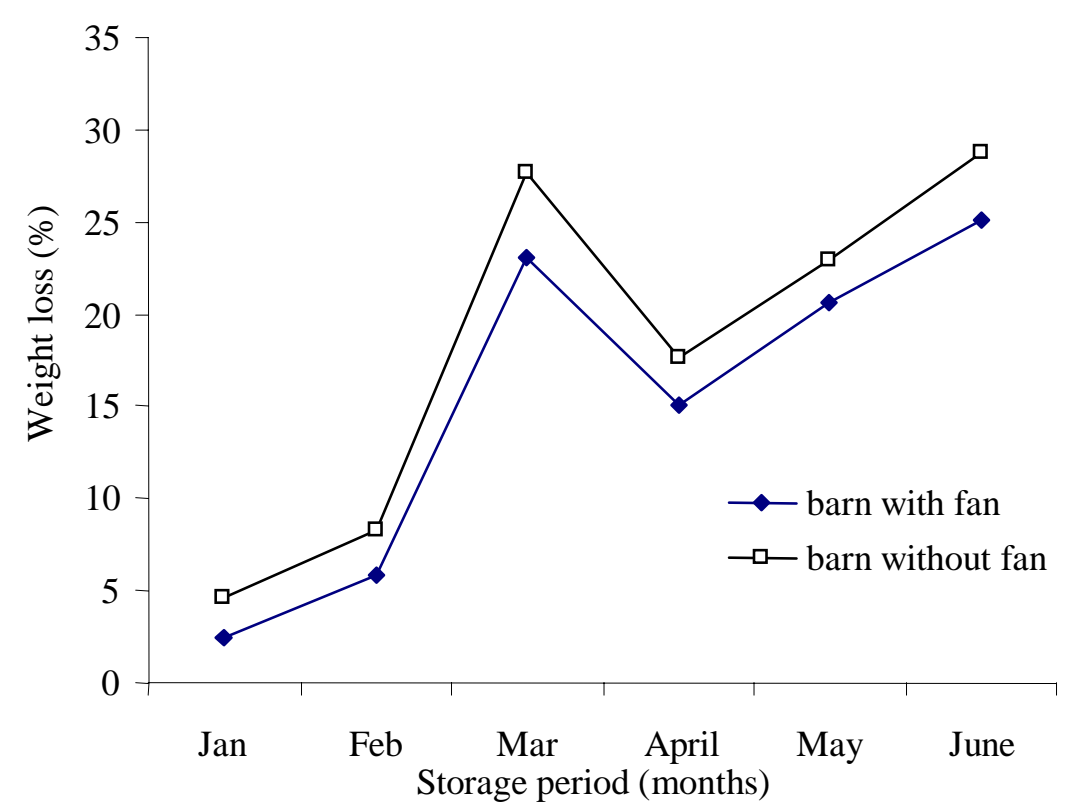

Figure 4: Monthly average percentage weight losses of yam tubers in the two barns

At the end of three month period, the tubers stored in the ventilated barn showed $4.7 \%$ less weight loss compared to the tubers in the barn without ventilation (Fig. 4). The tubers stored in the barn without fan continued to lose weight rapidly throughout the entire storage period.

\section{Rotting}

Table 1 shows the numbers and percentages of rotten tubers in each structure. No case of rotten tubers was observed in the first three months of storage in both barns. It was also observed that the barn with fan had low rate of rotten tubers, compared with the barn without fan. Only two tubers $(1.85 \%)$ out of the one hundred and eight tubers stored in the barn with fan decayed, while a total of 13 tubers (about 12\%) out of 108 tubers stored in the barn without fan decayed.

\section{Nutritional Parameters}

Tables 2 show the nutritional composition of the tubers before storage, after three months and after six months of storage in the two barns. The result shown is an average of three measurements. The difference in the nutritional content between the two barns was not statistically significant. From the Tables, it can be observed that 


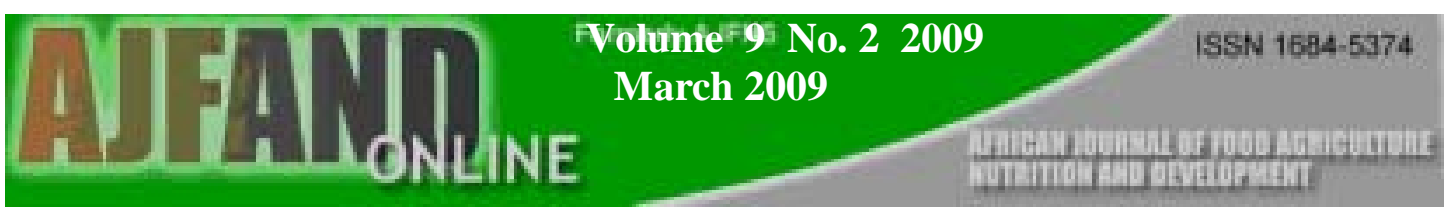

after six months of storage ash and crude fiber content increased while moisture, carbohydrate, phosphorus, calcium and protein content of the tuber were reduced.

\section{DISCUSSION}

The difference in temperature between the two barns may be attributed to the presence of fan which helped to improve airflow and this may have led to the slight decrease observed in the temperature inside the barn with fan as compared with barn without fan. Similarly the average humidity in the barn with fan which was slightly higher than that in the barn without fan, may be attributed to the lower temperature experienced in the barn with fan as compared with the barn without fan. A similar observation was recorded by other authors who worked on yam storage using pit structures $[14,15]$. The lower sprout weight observed in barn with fan could be due to the high rate of ventilation. This agrees with the findings of other researchers who reported that high rate of ventilation reduces the growth rate of vines in stored tubers [16]. Figure 4 shows the percentage weight loss of tubers stored in the two barns. It shows that the barn with fan had the least weight loss throughout the period of storage. The reduction observed in weight loss could be due to the little difference in temperature and humidity between the two barns and the reduction in sprout development and growth. Respiration, transpiration and sprouting are the factors responsible for weight loss [7] and low temperature and high humidity slow down these physiological processes in turn reducing weight loss. At the end of the third month, the tubers in the barn with fan showed $4.7 \%$ less weight loss compared to tubers stored in the barn without fan. The tubers in the barn without fan continued to lose weight more rapidly throughout the entire storage period compared to those stored in the barn with fan. This also confirmed that low temperature and high humidity during storage period slows down the rate of weight loss [17]. However, to achieve a significant reduction in weight loss, the storage temperature needs to be reduced to between $15-20^{\circ} \mathrm{C}[18]$.

No case of rotten tubers was observed in the first three months of storage (Table 1). Previous work also shows a similar trend [19]. It was also observed that the barn with fan had a low rate of rotten tubers, compared with the barn without fan. This shows that intermittent ventilation highly reduces incidence of rotting in stored yams.The reduction in rotting could be due to the fact that the forced air flow helps to disperse any accumulation of heat on or around the tubers which if allowed to remain could result in the rotting of the tubers in question.

Table 2 shows the nutritional composition of the tubers before storage, after three months and after six months of storage in the two barns.The Proximate and mineral composition of the common root tubers in Nigeria have been reported by many authors $[10,7]$. From the Tables, it can be observed that significant reductions in moisture, crude protein, carbohydrate phosphorus and calcium content occurred throughout the period of storage in both barns. Decrease in moisture and protein levels in stored yam tubers have been reported [19]. Also decrease in moisture content, crude protein, crude fat, ash, calcium and fibre content during cocoyam storage which is also a tropical tuber crop has been reported [20]. However, in this study the ash and fibre content of the tuber increased slightly at the end of the storage

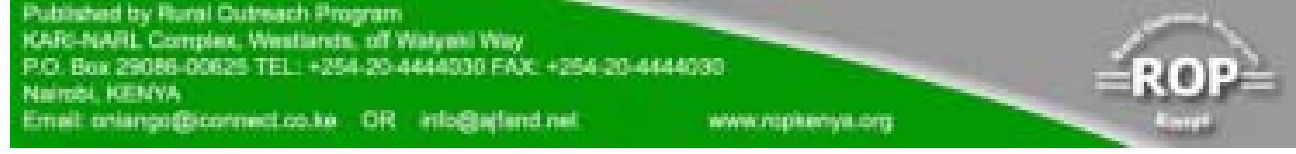


period.Reduction in moisture content and carbohydrate occurs due to respiration, transpiration and sprouting of the tuber. These are physiological activity promoted by high temperature and high relative humidity of the storage environment [6]. Respiration results in a steady loss of carbohydrate as carbon dioxide and water, while at the same time transpiratory loss of water occurs [6]. Protein values obtained after three months of storage also compare well with 1.6 and $1.99 \mathrm{~g} / 100 \mathrm{~g}$ obtained for Dioscorea alata and cassava respectively after a similar period of storage [10]. The decrease in protein content may have been affected by tannins reported to form complexes with protein, limiting their availability [10]. Generally edible yam does not contain any toxic component. However, some immature tissues of D. rotundata tend to accumulate trace amount of bitter components which are polyphenols or tannin compounds. It has been observed that the fat level in Dioscorea rotundata is generally low (Tables 2) the calcium content decreased from $12.2 \mathrm{mg}$ to $4.91 \mathrm{mg}$ and 4. $76 \mathrm{mg}$ in barn with fan and barn without fan, respectively after six months of storage.This could have been as the result of sprout development and growth, as some of the minerals are used for this physiological activity.Tuber and root crops are rich in carbohydrates.Generally, carbohydrate decreased slightly during the period of storage in both barns. It has been reported that the carbohydrate content of yam tuber decreases during storage due to conversion of starch to sugar and respiratory losses of sugar as carbon dioxide $[10,13]$. Slight differences were observed in moisture, ash, crude protein, phosphorus and calcium content between the two barns.

\section{CONCLUSION}

Generally, it can be concluded that intermittent forced air flow in stored yam tubers helps in reducing sprouting, weight loss and rotting. This could be due to the fact that the fan helps to disperse any accumulation of heat on or around the tubers. However, the economical advantage of intermittent air flow in stored yam tuber need to be further investigated. The study also shows reduction in nutritional content such as moisture, carbohydrate, protein, phosphorus and calcium during the storage period. 


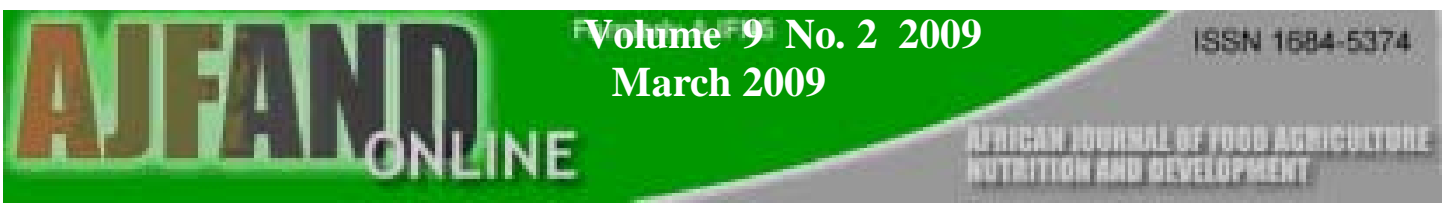

Table 1: $\quad$ Effects of storage conditions on rotting of yam tuber.

\begin{tabular}{|c|c|c|c|c|c|c|c|c|}
\hline & \multicolumn{8}{|c|}{ Months } \\
\hline & Jan & Feb & Mar & April & May & June & Tota & \\
\hline & & & & & & & no & $\%$ \\
\hline Barn with fan & - & - & - & 1 & - & 1 & 2 & 1.85 \\
\hline Barn without fan & - & - & - & 1 & 2 & 11 & 13 & 12.03 \\
\hline
\end{tabular}

Table 2: Nutritional Composition of fresh and stored yam tubers.

\begin{tabular}{|c|c|c|c|c|c|c|c|}
\hline \multirow[t]{2}{*}{ constituents } & \multicolumn{3}{|c|}{ Barn with fan } & \multicolumn{4}{|c|}{ Barn without fan } \\
\hline & $\begin{array}{l}\text { Before } \\
\text { storage }\end{array}$ & $\begin{array}{l}\text { After } 3 \\
\text { months }\end{array}$ & $\begin{array}{l}\text { After six } \\
\text { months }\end{array}$ & $\begin{array}{l}\text { Before } \\
\text { storage }\end{array}$ & $\begin{array}{l}\text { After } \\
\text { months }\end{array}$ & 3 & $\begin{array}{l}\text { After six } \\
\text { months }\end{array}$ \\
\hline Moisture \% & 71 & 66.86 & 56.6 & 71 & 64.38 & & 54.06 \\
\hline $\begin{array}{l}\text { Carbohydrate } \\
\text { (g) }\end{array}$ & 24.6 & 23.73 & 21.9 & 24.6 & 24.01 & & 22.05 \\
\hline $\operatorname{Ash}(\mathrm{g})$ & 1.2 & 1.18 & 1.27 & 1.2 & 0.74 & & 1.39 \\
\hline $\begin{array}{l}\text { Crude Protein } \\
(\mathrm{g} / \mathbf{1 0 0 g})\end{array}$ & 2.6 & 1.90 & 1.5 & 2.6 & 1.69 & & 1.26 \\
\hline $\begin{array}{l}\text { Phosphorus } \\
\text { (mg) }\end{array}$ & 18 & 6.71 & 6.83 & 18 & 6.02 & & 6.50 \\
\hline Calcium (mg) & 12.2 & 4.93 & 4.91 & 12.2 & 1.32 & & 4.76 \\
\hline Crude fiber \% & 0.95 & 1.20 & 1.07 & 0.95 & 1.72 & & 1.19 \\
\hline Crude Fat (g) & 0.27 & 0.22 & 0.18 & 0.27 & 0.16 & & 0.19 \\
\hline
\end{tabular}




\section{REFERENCES}

1. Opara LU Yam storage In: Bakker -Arekema et al. (eds). CIGR Handbook of Agricultural Engineering. Vol. IV. Agro Processing. 1999: 182 - 214. The American Society of Agricultural Engineers. St. Joseph. M.I.

2. IITA. Yam, research for development, IITA Publication Vol 1, 2007: 1-10

3. Igbeka JC Storage practices for yam in Nigeria, Agriculture Mechanization in Asia, Africa and Latin America. 1985: 16, 55 - 58.

4. Nwakiti AO and D Makurdi Traditional and some improved storage methods for root and tuber crops in Nigeria. In: Deutsche Stiftung Fur Internationale Entwicklung (DSE) (edi): Roots, Tubers and legumes, Bonn, 1989: 51-67.

5. Osagie AU The yam tuber in storage. Post Harvest Research Unit, University of Benin, Nigeria 1992: 107 - 173.

6. Passam HC, Read SJ and J E Rickard The respiration of yam tubers and its contribution to storage losses. Trop. Agric 1978; (55): 207 - 214.

7. Ikediobi $\mathbf{C O}$ and $\mathbf{E}$ Oti Some biochemical changes associated with post-harvest storage of white yam (discorea rotundata) tubers. J. Sci. Food Agric. 1983: (34); $1123-1129$.

8. Afoakwa EA and S Sefa-Dedeh Chemical composition and quality changes occurring in Dioscorea dumetorum pax tubers after harvest, Food Chemistry, 2001; (75), 85 - 91.

9. Onyeme $\mathbf{O}$ and A Idowu Physical and chemical changes in traditionally Stored Yam tubers , Journal of agricultural and food Chemistry, 1988: 10, $588-591$.

10. Sahore DA, Nemlin GJ and A Kamenan Changes in nutritional properties of yam (Dioscorea spp), green plantain (Musa spp) and cassava (Manihot esculenta) during storage Food Science and Technology, 2007(47), 81 - 88

11. Osunde ZD, Yisa MG and AM El-Okene Quality changes of yam under different storage structures. Proceedings of the $4^{\text {th }}$ International Conference and $25^{\text {th }}$ Annual General Meeting of the Nigerian Institution of Agricultural Engineers. 2003: 25.

12. Anderson JM and JSI Igram A Handbook of methods of analysis.

C. A. B International, 1989: 39. 
13. AOAC. Official methods of Analysis $14^{\text {th }}$ ed. Association of Official Analytical Chemists Washington, D.C, 1980.

14. Gerardin O, Nindjin C, Farah Z, Escher F, Stamp P and D Otokore Effect of storage system and sprout removal on post-harvest yam (Dioscorea spp.) fresh weight loss. Journal of Agricultural Science, Cambridge 1998: 130, 329 336.

15. Osunde ZD and MG Yisa effect of storage structures and storage period on weight loss and sprout growth on stored yams. Proceedings of the $1^{\text {st }}$ International Conference of NIAE , 2000: 22, 196-199.

16. Mozie O Effect of air flow on weight losses and sprouting of white yam tubers stored in the conventional barn. Tropical Root and Tuber Crops News Letter 1984: 13. 32-37.

17. Adesuyi SA The effect of different environmental conditions on the respiration patterns of stored yam tubers (Discorea rotundata poir) Report of Nigerian Stored Prod. Res. Inst. (1976 - 77) 1979.

18. Akinnusi OA, Oyeniran JO and O Sowunmi Effect of chemical treatmen on yams stored in an improved yam barn. Rep. Nigerian Store Prod. Res. Inst. 1984: $69-77$.

19. Ihekeronye AI and PO Ngoddy Integrated food science and technology for the tropics. McMillan Publishers Ltd. London, 1985: 266 - 282 and 366 - 368.

20. Enomfon JA and IB Umoh Effect of heat and tetracycline treatments on the food quality and acridity factors in cocoyam. Pakistan Journal of Nutrition 2004: 3(4), $240-243$. 